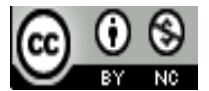

Jurnal Pendidikan Dasar Indonesia is licensed under

A Creative Commons Attribution-Non Commercial 4.0 International License

\title{
Pembelajaran Missouri Matematika KerJa Berbasis KONTEKSTUAL: MATERI BANgun RUANg Limas di SEKOLAH DASAR
}

\author{
Mariyam ${ }^{1)}$, Ahmad Yani ${ }^{2)}$, Rosmaiyadi ${ }^{3)}$, Nindy Citroresmi P, ${ }^{4)}$ Rika Wahyuni ${ }^{5)}$ \\ STKIP Singkawang, Kalimantan Barat ${ }^{1)}$, 3), 4), 5) \\ E-mail: mariyam.180488@gmail.com \\ E-mail: rosmaiyadialong@gmail.com \\ E-mail: nindy.citroresmi@gmail.com \\ E-mail: rikawahyuni142@gmail.com \\ Universitas Tanjungpura Pontianak, Kalimantan Barat ${ }^{2)}$ \\ E-mail:dr.ahmad.yani@gmail.com
}

\begin{abstract}
Abstrak: Tujuan penelitian adalah untuk mengetahui efektivitas model pembelajaran pembelajaran Missouri Matematika Kerja terhadap hasil belajar siswa di Sekolah Dasar. Penelitian ini menggunakan metode eksperimen dengan bentuk Pre-eksperimental design. Rancangan yang digunakan adalah One-Shot Case Study. Teknik dan alat pengumpul data untuk ketuntasan menggunakan teknik pengukuran dengan alat berupa Post-Test dan Delayed test, pengamatan aktivitas menggunakan teknik observasi langsung dengan alat berupa lembar pengamatan aktivitas guru dan siswa, dan teknik komunikasi tak langsung yang berupa penyebaran angket respon siswa. Berdasarkan hasil pengolahan data diperoleh model pembelajaran Missouri Matematika Kerja efektif digunakan terhadap hasil belajar siswa di Sekolah Dasar dengan kriteria (1) Pembelajaran menggunakan model pembelajaran Missouri Matematika Kerja (MMK) berbasis Kontekstual memberikan rata-rata rekapitulasi untuk persentase sebaran siswa berprilaku aktif sebesar 86,20\% (hampir seluruhnya) dan rata-rata rekapitulasi untuk persentase sebaran berprilaku pasif sebesar 13,80\% (sebagian Kecil); (2) Ketuntasan hasil belajar siswa berdasarkan hasil Post-Test dan Delayed Test mencapai ketuntasan klasikal. Berdasarkan Post-Test terdapat 27 orang siswa tuntas atau sebesar 87,07\% dan berdasarkan delayed test terdapat 25 orang siswa tuntas atau sebesar $80,65 \%$ dari 31 orang yang mengikuti tes hasil belajar. Berdasarkan hasil perhitungan menggunakan uji proporsi satu sampel yaitu uji $Z$, pada Post-Test diperoleh $Z_{\text {hitung }}>$ $Z_{\text {tabel }}$ yaitu $(3,03>2,33)$ dan pada Delayed Test diperoleh Zhitung $>$ Ztabel yaitu (2,36 > 2,33); (3) Respon siswa terhadap pembelajaran adalah positif dengan persentase tingkat kesetujuan terhadap pernyataan positif sebesar $85,16 \%$ (Sangat Setuju).
\end{abstract}

Kata Kunci: MMK Berbasis Kontekstual; Bangun Ruang Limas; Hasil Belajar; Ketuntasan Hasil Belajar

\section{Pendahuluan}

Belajar merupakan usaha memperoleh pendidikan. Proses belajar terjadi dalam diri siswa yang salah satu hakikatnya adalah terjadinya perubahan tingkah laku seseorang berkat adanya pengalaman. Perubahan itu akan memberikan hasil optimal jika perubahan itu memang dikehendaki oleh yang belajar, bermakna bagi siswa. Hal ini menegaskan bahwa proses aktif dari orang yang belajar dalam rangka mencapai tujuan pendidikan adalah faktor yang sangat penting, karena akan memberikan hasil yang lebih bermakna bagi tercapainya tujuan dan tingkat kualitas dari hasil belajar. Hal ini sesuai dengan pendapat yang dikemukakan oleh Suherman, Turmudi, Suryadi, dkk. (2003) bahwa aktivitas siswa harus terbuka yaitu kegiatan pembelajaran harus mengakomodasi kesempatan siswa untuk melakukan segala sesuatu secara bebas sesuai dengan kehendak mereka, selain itu juga dijelaskan bahwa aktivitas siswa dan ide-ide matematis dikatakan selaras, jika kebutuhan dan berpikir matematis siswa terperhatikan guru melalui kegiatan-kegiatan matematika yang bermanfaat untuk menjawab permasalahan lainnya.

Begitu pula halnya dengan pembelajaran matematika. Matematika merupakan disiplin ilmu yang mempunyai sifat khas. Kekhasan itu berkenaan dengan ide-ide atau konsepkonsep abstrak yang tersusun secara hirarkis. Mata pelajaran matematika perlu diberikan kepada semua peserta didik mulai dari sekolah dasar, untuk membekali peserta didik dengan kemampuan berpikir logis, analitis, sistematis, kritis, inovatif dan kreatif, serta kemampuan bekerjasama [1]. 
Berdasarkan wawancara dengan guru mata pelajaran marematika terkait proses pembelajaran yang terjadi, dalam pengajaran materi bangun ruang misalnya tabung, guru sudah menggunakan beberapa metode, diantaranya; metode ceramah, tanya jawab, penugasan dan demonstrasi dengan media berupa sketsa bangun dari karton dan alat peraga lain, namun hal tersebut kurang memberi efek yang yang baik terhadap hasil belajar. Kurang baiknya guru dalam memberikan materi pelajaran, memberikan perhatian dan penghargaan kepada siswa, maka motivasi belajar siswa menjadi menurun yang berimplikasi pada rendahnya hasil belajar matematika siswa [2]. Salah satu penyebabnya adalah karena didalam proses pembelajaran siswa hanya bersifat monoton, bersikap kurang aktif dimana siswa hanya jadi pengamat apa yang dilakukan guru. Hal ini menunjukkan rendahnya respon siswa dalam belajar.

Rendahnya respon siswa terhadap pembelajaran matematika menunjukkan ketidaksukaan siswa terhadap pelajaran tersebut. Hal ini timbul karena adanya sikap negative siswa terhdap pembelajaran. Adanya sikap nigatif tersebut akan berpengaruh terhadap hasil belajar siswa. Hal ini sejalan dengan referesi [3] yang menyatakan bahwa sikap negatif siswa terhadap matematika berpengaruh terhadap cara-cara siswa dalam mempelajari matematika, sehingga diduga bahwa sikap negatif siswa terhadap matematika, merupakan salah satu indikator penyebab rendahnya hasil belajar matematika siswa.

Materi yang menjadi pokok pembahasan dalam penelitian ini adalah geometri. Geometri merupakan salah satu cabang ilmu matematika yang mempelajari tentang bangun-bangun yang salah satu subbabnya adalah bangun ruang limas. Alasan dipilihnya materi limas karena materi ini cukup sulit dan dalam kehidupan sehari-hari contoh bangun ruang limas sedikit jenisnya, sehingga siswa perlu penanaman konsep lebih riil yang kemudian diarahkan dengan menggunakan pembelajaran kontekstual agar dapat mengkomunikasikan konsep-konsep yang mereka ketahui tentang limas dalam konteks dunia nyata.

Salah satu langkah untuk meningkatkan proses aktif dari orang yang belajar tersebut adalah dengan pembelajaran menggunakan model Missouri Matematika Kerja (MMK) Berbasis Kontekstual. Pemilihan model pembelajaran MMK berbasis kontekstual dalam penelitian ini berdasarkan pertimbangan bahwa proses pembelajaran harus menekankan kepada kreaktifitas anak dan guru merupakan salah satu faktor penting yang berperan dalam pencapaian tujuan pembelajaran. Dalam penerapannya, guru berperan menyajikan materi dengan konsep yang lebih menarik dan mengaitkannya dengan kehidupan sehari-hari (dunia nyata), kemudian siswa dikelompokkan kedalam kelompok kooperatif yang terdiri dari 4-5 siswa dan diberi alat peraga sehingga siswa mendapat pengalaman langsung dalam pemahaman konsep materi.

Missouri Matematika Kerja (MMK) atau Missouri Mathematics Project adalah model pembelajaran yang terstruktur seperti hanya SPM (Struktur Pembelajaran Matematika), namun MMK mengalami perkembangan langkah-langkah yang terstruktur dengan baik, dimana pada proses pembelajarannya guru berperan menyajikan materi secara lebih riil melalui alat peraga, demonstrasi melalui benda konkrit sehingga pemahaman konsep matematika terlihat lebih mudah dan nyata [4].

Missouri Matemtika Kerja adalah nama lain dari Missouri Mathematics Project dalam bahasa Indonesia. Missouri Mathematics Project adalah model pembelajaran yang dikembangkan oleh pengajar di Universitas Missouri yang bertujuan memudahkan atau membantu guru dalam mengajar matematika. Langkah-langkah: model pembelajaran MMK menurut referesi [5] terdiri dari: Review, Pengembangan, Latihan terkontrol, Seat Work, dan Penugasan. Pemilihan model pembelajaran MMK berbasis kontekstual dalam penelitian ini berdasarkan pertimbangan bahwa proses pembelajaran harus menekankan kepada kreaktifitas anak dan guru merupakan salah satu faktor penting yang berperan dalam pencapaian tujuan pembelajaran. Dalam penerapannya, guru berperan menyajikan materi dengan konsep yang lebih menarik dan mengaitkannya dengan kehidupan sehari-hari (dunia nyata), kemudian siswa dikelompokkan kedalam kelompok kooperatif yang terdiri dari 4-5 siswa dan diberi alat peraga sehingga siswa mendapat pengalaman langsung dalam pemahaman konsep materi.

Pembelajaran MMK dikolaborasikan dengan pendekatan kontekstual. Pendekatan pembelajaran kontekstual adalah pendekatan pembelajaran yang mengaitkan materi pembelajaran dengan situasi dunia nyata siswa, pembelajaran kontekstual lebih mengutamakan aktifitas siswa dalam pembelajaran sehingga siswa dapat menemukan konsep tentang materi pembelajaran dan mengaitkan konsep [6]. Dengan demikian melalui pendekatan kontekstual diharapkan hasil belajar dapat lebih bermakna bagi siswa, sehingga siswa dapat mengaplikasikan hasil belajarnya dalam kehidupan mereka dalam jangka panjang. Pendekatan Hal ini dimaksudkan untuk membantu anak memahami materi yang dimulai dengan dunia disekitarnya. Hal ini mengingat anak di usia Sekolah dasar kan lebih mudah memahami materi jika mereka mempelajari segala sesuatunya dari hal-hal yang sifatnya konkret. Sehingga pembelajaran matematika pada siswa sekolah dasar perlu berbagai dikreasinka dengan suatu pendekatan inovatif agar pembelajaran dapat diserap baik anak dan tidak mudah dilupakan. Sehingga pembelajaran jarus menarik, menyenangkan dan dekatk dengan dunia anak. Hal ini sejalan dengan referesi [7] bahwa Pendekatan kontekstual dalam pembelajarannya lebih bermakna, karena pembelajaran dilakukan melibatkan siswa secara aktif, sehingga pengetahuan siswa, perilaku siswa, dan keterampilan siswa dibangun atas kesadaran sendiri, serta dapat mengupayakan terjadinya proses pembelajaran yang efektif. 


\section{Metode PenElitian}

Bentuk penelitian yang digunakan dalam penelitian ini adalah Pre-Experimental Designs (nondesigns). Erdasarkan referesi [8] mengelompokkan tiga jenis desain penelitian yang lazim digunakan pada metode pre-exprimental design, yakni one-shot case study,one-group pretest-posttest design, dan intact-group comparison. Rancangan penelitian yang digunakan dalam penelitian ini adalah one shot case study, yaitu rancangan yang menggunakan satu kelompok sampel dimana siswa dikenakan perlakuan tertentu setelah itu diberikan tes untuk mengetahui ketuntasan hasil belajar siswa setelah diberikannya perlakuan tersebut. Dalam penelitian ini tes dilakukan dua kali yang pertama setelah perlakuan, selanjutnya setelah tes yang pertama beberapa kemudiandiberikan tes kembali yaitu delayed test. Sementara itu, pemberian umpan balik tertunda (delay feedback) adalah pemberian umpan balik tentang informasi prosedur dan hasil kerja terkait kemampuan yang masih dikuasai siswa setelah penerapan pembelajaran. Rancangan ini dapat digambarkan sebagai berikut:

Tabel 1.

Rancangan Penelitian

\begin{tabular}{cccc}
\hline Kelompok & Perlakuan & Post-test & Delayed Test \\
\hline Eksperimen & $\mathrm{X}$ & $\mathrm{T}_{1}$ & $\mathrm{~T}_{2}$
\end{tabular}

Keterangan :
$\mathrm{X} \quad=$ Perlakuan
$\mathrm{T}_{2} \quad=$ Delayed Test
$\mathrm{T}_{1} \quad=$ Post-test

Instrumen yang digunakan peneliti untuk mengumpulkan data-data dalam penelitian ini adalah tes hasil belajar, angket respon siswa dan lembar pengamatan terhadap aktivitas siswa dan aktivitas guru selama proses pembelajaran berlangsung. Pedoman observasi dalam penelitian ini berupa balanko/form yang didalamnya dimuat segi-segi, aspekaspek/tingkah laku yang perlu diamati dan dinilai pada waktu berlangsungnya kegiatan para peserta didik yang disesuaikan dengan RPP. Pengamatan dalam penelitian ini dilakukan secara langsung. Selama proses kegiatan pembelajaran berlangsung guru dapat melakukan penilaian dengan mengamati prilaku siswa secara langsung dalam menunjukkan kemampuannya. Dalam pelaksanaannya, peneliti meminta bantuan dua orang pengamat yang berasal dari mahasiswa untuk mengamati aktivitas siswa dan guru mata pelajaran matematika.

Tes hasil belajar yang digunakan dalam penelitian ini berupa soal-soal uraian mengenai materi bangun ruang limas yang dibuat dalam cerita komtekstual. Tes diberikan pada alhir pelaksanaan pembelajaran. Sebelum tes hasil belajar tersebut digunakan terlebih dahulu diuji validitas dan realibilitasnya. Berikut rekapitulasi hasil validitas soal tes.
Tabel 2.

Rekapitulasi Hasil Uji Coba Soal

\begin{tabular}{|c|c|c|c|c|}
\hline No & $\begin{array}{l}\text { Validitas } \\
\text { Empiris }\end{array}$ & $\begin{array}{c}\text { Daya } \\
\text { Pembeda }\end{array}$ & $\begin{array}{c}\text { Tingkat } \\
\text { Kesukaran }\end{array}$ & Ket \\
\hline 1. & $\begin{array}{c}0,5657 \\
\text { (Cukup) }\end{array}$ & $\begin{array}{c}0,24 \\
\text { (Cukup) }\end{array}$ & $\begin{array}{c}0,85 \\
\text { (Mudah) }\end{array}$ & Dipakai \\
\hline 2. & $\begin{array}{c}0,6643 \\
\text { (Tinggi) }\end{array}$ & $\begin{array}{l}0,275 \\
\text { (Cukup) }\end{array}$ & $\begin{array}{c}0,46 \\
\text { (Sedang) }\end{array}$ & Dipakai \\
\hline 3. & $\begin{array}{c}0,3684 \\
\text { (Rendah) }\end{array}$ & $\begin{array}{c}0,044 \\
\text { (Jelek) }\end{array}$ & $\begin{array}{c}0,73 \\
\text { (Mudah) }\end{array}$ & Dirombak \\
\hline $4 .$. & $\begin{array}{c}0,6544 \\
\text { (Tinggi) }\end{array}$ & $\begin{array}{c}0,24 \\
\text { (Cukup) }\end{array}$ & $\begin{array}{c}0,63 \\
\text { (Sedang) }\end{array}$ & Dipakai \\
\hline 5. & $\begin{array}{c}0,7911 \\
\text { (Tinggi) }\end{array}$ & $\begin{array}{c}0,23 \\
\text { (Cukup) }\end{array}$ & $\begin{array}{c}0,38 \\
\text { (Sedang) }\end{array}$ & Dipakai \\
\hline
\end{tabular}

Untuk perhitungan reliabilitasnya, diperoleh koefisien reabilitas uji coba soal sebesar 0,61125 yang berarti soalsoal yang diujicobakan tersebut reliabel dan termasuk dalam kategori tinggi.

Untuk pengamatan aktivitas siswa dan guru digunakan lembar pengamatan aktivitas yang dilakukan oleh dua orang pengamat yang telah dipersiapkan oleh peneliti. Untuk pengamatan aktivitas siswa terdapat prilaku siswa aktif dan prilaku siswa pasif yang dalam setiap langkahnya dihitung jumlah sebaran siswanya. Selanjutnya Meghitung persentase frekuensi sebaran siswa untuk setiap kategori prilaku. Tafsiran persentase sebaran siswa sebagai berikut:

Tabel 3.

Tafisiran Sebaran Persentase Siswa

\begin{tabular}{ccc}
\hline No & Nilai $(\boldsymbol{\%})$ & Kriteria \\
\hline 1. & 0 & Tidak ada \\
2. & $1-25$ & Sebagian Kecil \\
3. & $26-49$ & Hampir Separuhnya \\
4. & 50 & Separuhnya \\
5. & $51-79$ & Sebagian besar \\
6. & $80-99$ & Hamper seluruhnya \\
7. & 100 & Seluruhnya
\end{tabular}

Berdasarkan referensi [9].

Untuk aktivitas guru dalam pembelajaran, setiap hasil pengamatan yang dilakukan terhadap aktivitas guru dijumlahkan. Hasil akhir dari perhitungan tersebut kemudian dianalisis. Untuk mengetahui respon siswa, hasil angket respon siswa dianalisis menggunakan statistik deksriptif dalam bentuk persentase yang dikelompokkan kedalam beberapa kriteria penilaian. Dalam angket respon siswa terdapat pernyataan positif dan pernyataan negative. Respon siswa terhadap pembelajaran dikatakan positif apabila respon positif siswa untuk pernyataan positif lebih besar dari respon negatif siswa untuk pernyataan negatif.

\section{HASIL DAN PEMBAHASAN}

A. Aktivitas Siswa dan Guru Selama Proses Pembelajaran

Perbandingan rata-rata jumlah dan persentase sebaran siswa dalam setiap tahapanya selama proses pembelajaran yang berlangsung selama tiga kali pertemuan, berikut akan disajikan tabel dan diagram rekapitulai jumlah dan persentase sebaran siswa selama proses pembelajaran. 
Tabel 4.

Rekapitulasi Sebaran Siswa Selama Proses Pembelajaran

\begin{tabular}{|c|c|c|c|c|c|}
\hline \multirow[t]{2}{*}{$\begin{array}{l}\mathbf{N} \\
\mathbf{0}\end{array}$} & \multirow[t]{2}{*}{$\begin{array}{l}\text { Sintaks } \\
\text { Kegiatan }\end{array}$} & \multicolumn{2}{|c|}{$\begin{array}{c}\text { Rata-rata } \\
\text { Jumlah Sebaran } \\
\text { siswa } \\
\end{array}$} & \multicolumn{2}{|c|}{$\begin{array}{c}\text { Rata-rata } \\
\text { Persentase } \\
\text { sebaran siswa } \\
\end{array}$} \\
\hline & & Aktif & Pasif & Aktif & Pasif \\
\hline 1 & Tahap Review & 25 & 7 & $78,93 \%$ & $\begin{array}{c}21,07 \\
\%\end{array}$ \\
\hline 2 & $\begin{array}{l}\text { Tahap } \\
\text { Pengembangan }\end{array}$ & 27 & 5 & $85,3 \%$ & $14,7 \%$ \\
\hline 3 & $\begin{array}{l}\text { Tahap Latihan } \\
\text { Terkontrol }\end{array}$ & 28 & 3 & $89,5 \%$ & $10,5 \%$ \\
\hline 4 & $\begin{array}{l}\text { Tahap Seat } \\
\text { Work }\end{array}$ & 28 & 3 & $89,6 \%$ & $10,4 \%$ \\
\hline 5 & $\begin{array}{l}\text { Tahap } \\
\text { Penugasan }\end{array}$ & 28 & 4 & $87,4 \%$ & $11,6 \%$ \\
\hline & Jumlah & 136 & 22 & $430,73 \%$ & $\begin{array}{c}68,27 \\
\%\end{array}$ \\
\hline & Rat-rata & $\begin{array}{c}27,2 \approx \\
27\end{array}$ & $4,4 \approx 4$ & $86,2 \%$ & $13,8 \%$ \\
\hline \multicolumn{4}{|c|}{$\begin{array}{c}\text { Kriteria Tafsiran Harga Persentase Sebaran } \\
\text { Siswa }\end{array}$} & $\begin{array}{l}\text { Hampir } \\
\text { seluruhn } \\
\text { ya }\end{array}$ & $\begin{array}{l}\text { Sebagian } \\
\text { kecil }\end{array}$ \\
\hline
\end{tabular}

Dari tabel di atas tampak bahwa rata-rata jumlah sebaran siswa kategori berprilaku aktif selalu lebih besar dari jumlah siswa berkategori pasif. Untuk tahap review rata-rata jumlah sebaran siswa berperilaku aktif sebanyak 25 orang atau sebesar 78,93\% dengan rata-rata jumlah sebaran siswa berprilaku pasif sebanyak 7 orang atau sebesar $21,07 \%$. Untuk tahap pengembangan rata-rata jumlah sebaran siswa berperilaku aktif sebanyak 27 orang atau sebesar $85,3 \%$ dengan rata-rata jumlah sebaran siswa berprilaku pasif sebanyak 5 orang atau sebesar $14,7 \%$. Untuk tahap latihan terkontrol dan seat work rata-rata jumlah sebaran siswa berperilaku aktif adalah sama yaitu sebanyak 28 orang atau sebesar $89,5 \%$ dan $89,6 \%$, dengan rata-rata jumlah sebaran siswa berprilaku pasif sebanyak 3 orang atau sebesar $10,5 \%$ dan $10,4 \%$. Selanjutnya pada tahap penugasan rata-rata jumlah siswa berprilaku aktif sebanyak 28 orang atau sebesar $87,4 \%$ dengan rata-rata jumlah sebaran siswa berprilaku pasif sebanyak 4 orang atau sebesar $11,6 \%$. Dalam hal ini ada sedikit perbedaan perhitungan yang mungkin disebabkan karena pada setiap tahapnya ada pembulatan bilangan sehingga ada sedikit perbedaanpada angka-angkanya. Persentase sebaran siswa yang berprilaku aktif dan jumlah siswa yang berprilaku pasif dalam proses pembelajaran dapat digambarkan melalui diagram berikut:

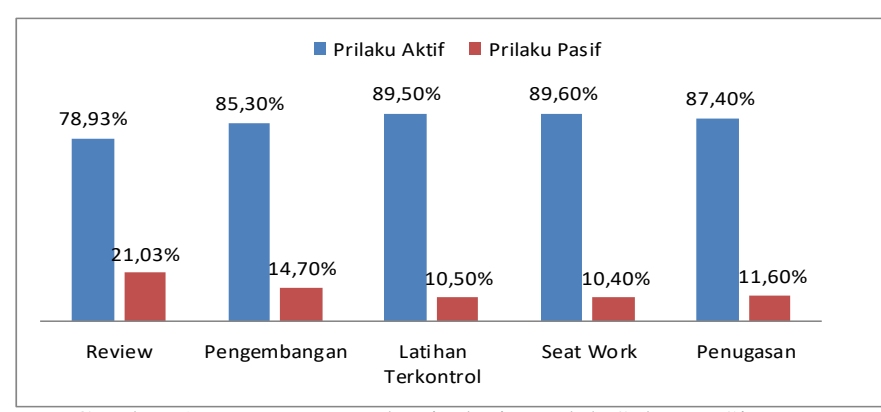

Gambar 1. Persentase Rekapitulasi Jumlah Sebaran Siswa Dalam Setiap Tahap Pembelajaran
Secara keseluruhan berikut Rata-Rata Persentase Sebaran Siswa yang berprilaku aktif dan yang berprilaku pasif.

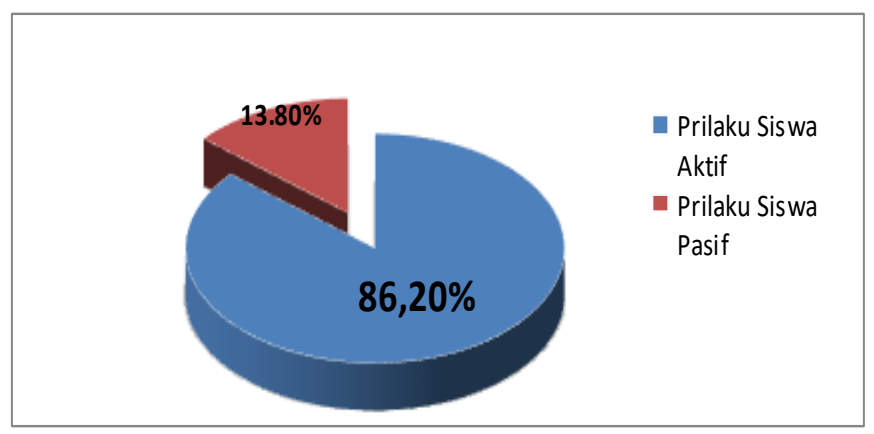

Gambar 2. Rata-Rata Persentase jumlah Sebaran Siswa Selama Proses Pembelajaran

Dalam diagram tersebut terlihat bahwa rata-rata persentase jumlah sebaran siswa berprilaku aktif selama proses pembelajaran adalah sebesar $86,20 \%$ yang dalam tafsiran harga persentase sebaran siswa berada dalam kriteria hampir seluruhnya dan rata-rata persentase jumlah sebaran siswa berprilaku pasif selama proses pembelajaran adalah sebesar $13,80 \%$ yang dalam tafsiran harga persentase sebaran siswa berada dalam kriteria sebagian kecil.

Tabel 5.

Rekapitilasi Penilaian Aktivitas Guru Selama Proses Pembelajaran

\begin{tabular}{ccc}
\hline No & Pertemuan & $\begin{array}{c}\text { Jumlah Poin Sesuai Kualitas } \\
\text { Pengamatan }\end{array}$ \\
\cline { 2 - 3 } 1 & Ke-1 & 96 \\
2 & Ke-2 & 98 \\
3 & Ke-3 & 93 \\
& Jumlah & 287 \\
& Rata-rata & 95,67 \\
& Kriteria & Sangat Baik \\
\hline
\end{tabular}

Dari Tabel 5 di atas dapat diketahui bahwa aktivitas guru selama 3 kali pertemuan berada dalam kategori sangat baik, hal ini berrati pembelajaran MMK berbasis kontekstual dapat diterapkan dengan baik di sekolah. Dari uraian di atas dapat diketahui bahwa model MMK berbasis kontekstual dapat memperbaiki aktivitas siswa. Hasil ini sesuai dengan hasil penelitian referensi [10] yang menyebutkan bahwa hasil analisis terhadap aktivitas siswa baik dalam kelompok maupun individu menunjukkan terjadinya peningkatan aktivitas dari siklus I ke siklus II. Jadi dapat dikatakan bahwa penerapan model pembelajaran MMP dapat meningkatkan aktivitas siswa serta meningkatkan hasil belajar siswa.

\section{B. Hasil Post-test dan Delayed-test}

Hasil post-test dan delayed test pada Tabel 6 dapat dilihat bahwa terdapat perbedaan persentase ketuntasan hasil belajar siswa. Dari hasil pengolahan data diperoleh adanya penurunan persentase ketuntasan hasil belajar siswa pada delayed test jika dibandingkan dengan persentase ketuntasan hasil belajar siswa pada post-test dalam menyelesaikan soal mengenai bangun ruang limas. Hal ini diduga disebabkan guru yang mengajar kurang mengaitkan materi sebelumnya 
yang dilakukan pada saat penelitian, sehingga pada saat siswa mengerjakan soal delayed test persentase jumlah siswa yang tuntas lebih kecil yaitu sekitar $80,64 \% \approx 81 \%$ dibandingkan persentase jumlah siswa yang tuntas pada saat mengerjakan soal pos-test $(87 \%)$.

Tabel 6. Perbandingan Persentase Ketuntasan Hasil Belajar Siswa Pada Post-Test dan Delayed Test

\begin{tabular}{ccc}
\hline No & Kategori test & Persentase Ketuntasan \\
\hline 1. & Post-Test & $87 \%$ \\
2. & Delayed Test & $81 \%$ \\
\hline \multicolumn{2}{c}{ Berdasarkan uji Z Proporsi } & diperoleh nilai Zhitung $>$
\end{tabular}

Berdasarkan uji Z Proporsi diperoleh nilai Zhitung > Ztabel yaitu ( 3,03 > 2,33), maka Ho ditolak. Hal ini bararti Ha diterima yaitu persentase ketuntasan hasil belajar siswa pada materi bangun ruang limas berdasarkan Post-Test setelah diajarkan menggunakan model MMK berbasis PMR lebih besar dari $60 \%$. Selanjutnya untuk hasil tes delayed test juga diperoleh nilai Zhitung > Ztabel yaitu $(2,36>2,33)$, maka Ho ditolak. Hal ini bararti Ha diterima yaitu persentase ketuntasan hasil belajar siswa pada materi bangun ruang limas berdasarkan delayed test setelah diajarkan menggunakan model MMK berbasis Kontekstual lebih besar dari $60 \%$. Tercapainya ketuntasan hasil belajar siswa menunjukkan bahwa pembelajaran dengan menggunakan model MMK berbasis kontekstual berpengaruh terhadap prestasi belajar siswa. Hal ini sesuai dengan hasil penelitian (Faradhila, dkk, 2013) yang menyebutkan bahwa Missouri Mathematics Project menghasilkan prestasi belajar matematika yang lebih baik daripada model pembelajaran langsung, baik secara umum maupun ditinjau pada masingmasing tingkat kemampuan spasial.

\section{Respon Siswa Terhadap Pembelajaran}

Pernyataan yang mengarah kepada sikap positif terhadap penerapan model pembelajaran MMK berbasis Kontekstual adalah pernyataan dengan no 1, 2, 5, 7, dan 10. Dari tabel 4.7 diperoleh jumlah persentase untuk kategori (SS) dan (S) $=90,97 \%$. Sedangkan jumlah persentase untuk (STS), (TS) dan (R) $=9,03 \%$. Ini berarti respon siswa terhadap penerapan model pembelajaran MMK berbasis Kontekstual adalah positif dengan persentase tingkat kesetujuan $=85,16 \%$ dengan jumlah skor 660 yang bararti berada pada daerah sangat setuju. Secara kontinu dapat digambarkan sebagai berikut:

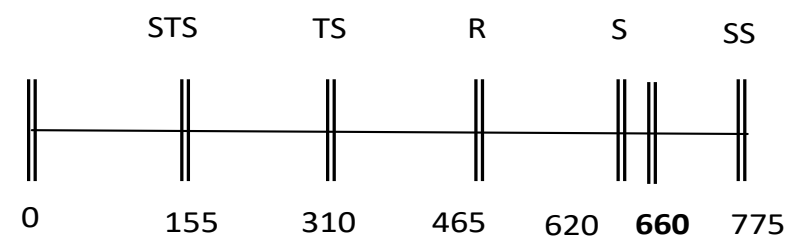

Pernyataan yang mengarah kepada sikap negatif terhadap penerapan model pembelajaran MMK berbasis Kontekstual adalah pernyataan dengan no 3, 4, 6, 8 dan 9. Dari tabel 4.8 diperoleh jumlah persentase untuk kategori (STS), dan (TS) $=79,36 \%$. Sedangkan jumlah persentase untuk kategori $(\mathrm{SS}),(\mathrm{S})$ dan $(\mathrm{R})=20,64 \%$. Ini berarti respon siswa untuk pernyataan negatif terhadap penerapan model pembelajaran MMK berbasis Kontekstual adalah negatif dengan persentase tingkat ketidaksetujuan $=78,98 \%$ dengan jumlah skor 612 yang bararti berada pada daerah tidak setuju. Secara kontinu dapat digambarkan sebagai berikut:

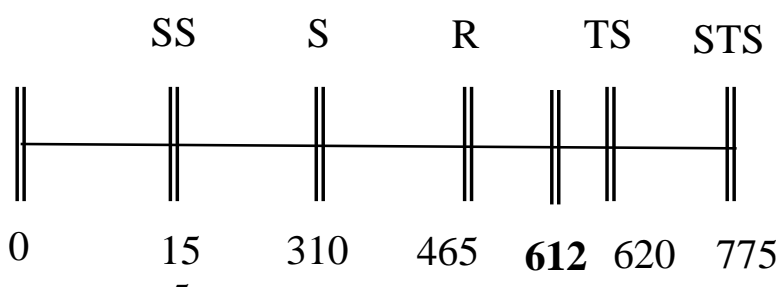

Berdasarkan hasil yang diperoleh persentase untuk pernyataan positif/tanggapan positif sebesar $85,16 \%$ dan persentase untuk pernyataan negatif/tanggapan negatif sebesar 78,98\%. Dari hasil tersebut dapat disimpulkan bahwa persentase untuk pernyataan positif lebih besar dari persentase untuk pernyataan negatif. Hal ini menunjukkan bahwa respon siswa terhadap penerapan model pembelajaran MMK berbasis Kontekstual adalah positif.

\section{KESIMPULAN DAN SARAN}

Kesimpulan dari hasil penelitian yang telah dilakukan adalah model pembelajaran Missouri Matematika Kerja efektif digunakan terhadap hasil belajar siswa di Sekolah Dasar dengan kriteria : pembelajaran menggunakan model pembelajaran MMK berbasis Kontekstual efektif dapat mengaktifkan siswa dengan persentase siswa berprilaku aktif selalu lebih besar dari siswa berprilaku pasif dalam setiap tahap pembelajarannya, terdapat ketuntasan hasil belajar siswa brdasarkan hasil Post-Test dan Delayed Test setelah diterapkannya model pembelajaran MMK berbasis Kontekstual pada materi bangun ruang limas mencapai ketuntasan klasikal dan respon siswa terhadap pembelajaran pada materi bangun ruang limas dengan menggunakan model pembelajaran MMK berbasis Kontekstual adalah positif dengan persentase tingkat kesetujuan terhadap pernyataan positif sebesar 85,16\% (Sangat Setuju) dan persentase tingkat ketidaksetujuan terhadap pernyataan negatif sebesar 78,98\% (Tidak Setuju).

\section{DAFTAR PUSTAKa}

[1] Rosmaiyadi, R. (2017). Analisis Kemampuan Berpikir Kritis Matematis Siswa Dalam Learning Cycle $7 e$ Berdasarkan Gaya Belajar. Aksioma: Jurnal Program Studi Pendidikan Matematika, 6(1), 12-19.

[2] Sahidin, L., \& Jamil, D. (2013). Pengaruh Motivasi berprestasi dan Persepsi Siswa tentang Cara Guru mengajar terhadap Hasil Belajar Matematika. Jurnal Pendidikan Matematika, 4(2), 212-222.

[3] Setiawan, R. H., \& Harta, I. (2014). Pengaruh Pendekatan Open-ended dan Pendekatan Kontekstual terhadap Kemampuan Pemecahan Masalah dan Sikap Siswa terhadap 
Matematika. Jurnal Riset Pendidikan Matematika, 1(2), 241257.

[4]Widdiharto, R. (2010). Model-model Pembelajaran Matematika SMP. Disampaikan pada Diklat Instruktur/Pengembangan Matematika SMP jenjang Dasar tahun 2004.

[5] Krismanto. (2003). Beberapa Teknik, Model dan Strategi dalam Pembelajaran Matematika . Disampaikan pada Pelatihan Instruktur/Pengembangan SMU tahun 2003.

[6] Rosmaiyadi, R., Mariyam, M., \& Juliyanti, J. (2018). Pemahaman Konsep Matematis Siswa Dengan Strategi Pembelajaran Group To Gruop Exchange Berpendekatan Kontekstual. Jurnal Penelitian dan Pembelajaran Matematika, 11(1).

[7] Hardiyanti, S., Maulana, M., \& Julia, J. (2017). Pengaruh Pendekatan Kontekstual Berbantuan Jarimatika Terhadap Kemampuan Pemahaman Matematis dan Keterampilan Berhitung Siswa Pada Materi Perkalian. Jurnal Pena Ilmiah, 2(1), 881-890.
[8] Sugiyono. (2012). Metode Penelitian Kuantitatif, Kualitatif, dan Kombinasi. Bandung; Alfabeta.

[9] Mantili, Elvira DS. (2010). Implikasi Pendekatan STM Terhadap Keterampilan Proses Sains Dan Hasil Belajar Siswa Dalam Pelajaran Pencemaran Air di Kelas VII SMP Pertiwi Pontianak.Universitas Tanjung Pura Pontianak.

[10] Kurniasari, V. H. D., \& Susanto, S. (2015). Penerapan Model Pembelajaran Missouri Mathematics Project Dalam Meningkatkan Aktivitas Siswa Dan Hasil Belajar Siswa Sub Pokok Bahasan Menggambar Grafik Fungsi Aljabar Sederhana Dan Fungsi Kuadrat Pada Siswa Kelas X Sma Negeri Balung Semester Ganjil Tahun. Pancaran Pendidikan, 4(2), 153-162. 